\title{
OCAW V. AMERICAN CYANAMID: THE SHRINKING OF THE OCGUPATIONAL SAFETY AND HEALTH AGT
}

\author{
RICHARD LEWIS $\dagger$
}

In 1978 the American Cyanamid Company initiated a policy at its chemical plant in Willow Island, West Virginia that led to the surgical sterilization of five women employees. ${ }^{1}$ The policy was designed to eliminate the risk of fetal exposure to toxic workplace chemicals ${ }^{2}$ by assuring that no women who could possibly carry a fetus were present in designated areas of the plant. ${ }^{3}$ Company personnel, including the

† B.A. 1976, Tufts University; M.P.H. 1981, University of Michigan School of Public Health; J.D. Candidate, 1986, University of Pennsylvania. The author wrote this Comment while a student at the University of Pennsylvania Law School.

1 See Oil, Chem. \& Atomic Workers v. American Cyanamid Co., 741 F.2d 444, 445-46 (D.C. Cir. 1984).

2 See id. at 446.

3 The company's sterilization policy, which was adopted primarily in response to hazards to fetuses associated with lead, see id. at 446, applied only to women. According to expert testimony presented during Occupational Safety and Health Administration (OSHA) rulemaking on the lead standard, hazards to fetuses are not completely eliminated by keeping fertile and pregnant women out of a lead-exposure workplace; exposure of male employees may also be hazardous. Although the exposure of men to lead toxicity results primarily in decreased sex drive, impotence, and sterility, sperm cells can be affected and in some cases pass on genetic damage to fetuses. See OSHA Preamble to Final Standards, Occupational Exposure to Lead, 43 Fed. Reg. 52,952, 52,959-60 (1978) [hereinafter cited as OSHA Lead Preamble]. Thus, American Cyanamid's sterilization policy was vulnerable to attack as illegal sex discrimination.

The Oil, Chemical \& Atomic Workers union and the women affected by American Cyanamid's sterilization policy filed suit under section 703(a)(1) of Title VII of the Civil Rights Act of 1964, 42 U.S.C. $\$ 2000 \mathrm{e}-2(\mathrm{a})(1)(1982)$, but this suit ended in settlement. See Oil, Chem. \& Atomic Workers v. American Cyanamid Co., 741 F.2d 444, 450 n.1 (D.C. Cir. 1984). Recent decisions, however, hold that a reproductive hazards policy applicable solely to women may violate Title VII. In Wright v. Olin Corp., 697 F.2d 1172 (4th Gir. 1982), the court held that evidence of the existence and operation of Olin's "fetal vulnerability" program, which restricted women's contact with certain toxic chemicals, established a prima facie violation of Title VII. Olin could overcome this presumption of violation, however, by establishing that, because the chemicals posed a reproductive risk for fertile and pregnant women but not for men, the policy was a business necessity. Id. at 1189-90. In Hayes v. Shelby Memorial Hosp., 726 F.2d 1543 (11th Cir. 1984), the Eleventh Circuit followed the Olin approach, holding that a hospital's policy of dismissing pregnant $\mathrm{x}$-ray technicians was presumed to be facially discriminatory under Title VII. The hospital could overcome this presumption by demonstrating that the offspring of women who were exposed to $x$ rays while fertile or pregnant faced a substantial risk of harm, whereas the offspring of male workers exposed to x-rays faced no such risk. Id. at 1548 \& n.8; see also Zuniga v. Kleberg County Hosp., 692 F.2d 986 (5th Cir. 1982) (holding that the hospital's concern for risks to fetuses and fear of liability did not constitute "business necessity" where the hospital could have employed a less discriminatory alternative by granting a 
plant manager, doctor, and nurse, conducted a series of small group meetings with women employees. At these meetings, the company explained that any woman between the ages of sixteen and fifty would be deemed of child-bearing capacity and would be terminated unless she presented proof of surgical sterilization. ${ }^{4}$ There were thirty women employed throughout the plant, but upon full implementation of the policy, there would be only seven jobs available in the plant for the women who had not chosen sterilization. ${ }^{5}$ For the women who did not obtain one of the seven positions, the policy presented a choice between undergoing sterilization and being fired. Five women, who were being exposed to lead in the inorganic pigments department, underwent surgical sterilization between the months of February and July $1978 .^{6}$

In 1979, the Secretary of Labor cited the Willow Island plant for a violation of the Occupational Safety and Health Act (OSH Act or Act) "general duty clause." The citation, which alleged that the employer's sterilization policy was a hazard that violated the OSH Act, read as follows:

The employer did not furnish employment and a place of employment which were free from recognized hazards that were causing or were likely to cause death or serious physical harm to employees, in that: The employer adopted and implemented a policy which required women employees to be sterilized in order to be eligible to work in the areas of the plant where they would be exposed to certain toxic substances ....8

The company contested this citation and won on a motion for summary judgment before an administrative law judge. ${ }^{9}$ This result

leave of absence rather than terminating a pregnant $x$-ray technician); Andrade, The Toxic Workplace: Title VII Protection for the Potentially Pregnant Person, 4 Harv. WOMEN's L.J. 71 (1981).

4 See Oil, Chem. \& Atomic Workers v. American Cyanamid Co., 741 F.2d 444, 446 (D.C. Cir. 1984).

s See id.

- See id.

7 Occupational Safety and Health Act of 1970, § 5(a)(1), 29 U.S.C. § 654(a) (1982). The clause reads as follows: "Each employer . . . shall furnish to each of his employees employment and a place of employment which are free from recognized hazards that are causing or are likely to cause death or serious physical harm to his employees ...."

8 Oil, Chem. \& Atomic Workers v. American Cyanamid Co., 741 F.2d 444, 447 (D.C. Cir. 1984).

American Cyanamid Co., 1980 O.S.H. Dec. (CCH) I 24,720. The Oil, Chemical \& Atomic Workers union represented the women affected by the sterilization policy. The union exercised its right to participate as a party to the proceedings at the ALJ level, see Occupational Safety and Health Act of 1970, § 10(c), 29 U.S.C. § 659(c) 
was affirmed first by the Occupational Safety and Health Review Commission $^{10}$ and then by the D.C. Circuit Court of Appeals in Oil, Chemical $\mathcal{E}^{\circ}$ Atomic Workers v. American Cyanamid Co. (OCAW). ${ }^{11}$ Writing for the court, Judge Bork ruled that a policy requiring sterilization is not a "hazard" within the meaning of the general duty clause of the OSH Act. ${ }^{12}$

(1982), and filed the petition for review at the circuit court level. The union, however, mistakenly named the Occupational Health and Safety Review Commission as the respondent. Subsequently, the union filed a motion to dismiss the Commission as respondent on appeal and make American Cyanamid the respondent instead. This motion was granted. Oil, Chem. \& Atomic Workers v. Occupational Safety and Health Review Comm'n, 671 F.2d 643, 653 (D.C. Cir.), cert. denied, 459 U.S. 905 (1982).

10 Ámerican Cyanimid [sic] Co., 1981 O.S.H. Dec. (CCH) II 25,338.

11741 F.2d 444 (D.C. Cir. 1984). In reaching its decision the OCAW court employed three techniques of statutory construction: reliance on precedent, reliance on congressional intent, and reliance on a policy to limit employer liability. The Occupational Safety and Health Review Commission (OSHRC) relied solely on an analysis of congressional intent. See American Cyanimid [sic] Co., 1981 O.S.H. Dec. (CCH) II 25,338 , at 31,430 . The Commission's decision was restricted to a construction of the general duty clause, section $5(\mathrm{a})(1)$, whereas the $O C A W$ court's construction extended to the purpose section and addressed the scope of the entire act. See infra notes 79-84 and accompanying text. Although the $O C A W$ court expressed its agreement with sections of the Commission's congressional intent discussion, it did not defer to the Commission, but rather gave the Act its own construction. Where the congressional intent is clear, the deference issue is never reached. Chevron, U.S.A. v. Natural Resources Defense Council, 104 S. Ct. 2778, 2781-82 (1984); FEC v. Democratic Senatorial Campaign Comm., 454 U.S. 27, 31 (1981). Judge Bork found that, since it was difficult to speculate about what Congress's intent with respect to the general duty clause would have been had it actually considered the "hazard" of employer-offered choice between injury and discharge, it was "safer" to confine the general duty clause to hazards that "we know Congress had in mind." OCAW, 741 F.2d at 449.

12 OCAW, 741 F.2d at 449. This Comment's primary criticism of the OCAW decision is that it incorrectly construed the OSH Act in finding that the Secretary did not have the statutory authority even to reach the company sterilization requirement. If the $O C A W$ court had found that the Secretary did have the authority to reach the sterilization requirement, that alone would not have been sufficient to give effect to the citation under the general duty clause. To issue a citation under the general duty clause, the Secretary must state with particularity precisely what the employer has done wrong, describe specific steps the employer should have taken to avoid the citation, and demonstrate the feasibility of taking those steps. See, e.g., Donovan v. Royal Logging Co., 645 F.2d 822, 829 (9th Cir. 1981).

Had the American Cyanamid citation not been dismissed at the summary judgment stage, there would have been an inquiry into the possibility of abating the hazard. There are at least five possible means of protecting the fetus from lead exposure that, applied independently or in combination, offer alternatives to requiring the sterilization of women workers: (1) reduction of ambient air lead levels; (2) reduction of lead levels in the blood of fertile women employees; (3) medical surveillance and removal of fertile women whose blood lead levels exceed a standard deemed to be unsafe for pregnant women (OSHA sets this level at 30 milligrams per 100 grams of blood, see OSHA Lead Preamble, supra note 3 , at 52,960); (4) family planning to prevent pregnancy of lead-exposed workers; and (5) the shutdown of production in areas of the plant where workers' blood lead levels exceed the OHSA standard for pregnant women. Each of these alternatives was deemed infeasible or ineffective by American Cyanamid. See Reply Brief for Petitioners at 20 n.28, 22 n.29, 23 n.30, OCAW; see also infra note 54 
In Part I of this Comment I offer a critique of the OCAW decision. First, I focus on Judge Bork's determination of the scope of the OSH Act, in which he relied on precedent, congressional intent, and a policy argument for limiting employer liability. I contend that the court misapplied these techniques of statutory construction and thus misconstrued the Act. Second, I discuss the potentially grave impact on occupational health policy that the decision forbodes. In Part II, based on statutory language, legislative history, and OSH Act case law, I suggest an alternative approach to determining the scope of the Act that focuses on the employer's role in creating hazards. This approach would both protect worker health and establish a limit to employer liability. Unlike Judge Bork's formulation, it avoids a draconian choice between limitless liability and employer immunity.

\section{The OCAW Decision: CRITIQue}

\section{A. Judge Bork's Construction of the OSH Act}

Judge Bork's finding that American Cyanamid's sterilization policy did not qualify as a hazard under the OSH Act was based on his interpretation of precedent and congressional intent as well as on his fear that to find otherwise would lead to "unforeseeable consequences" in the form of unbounded employer liability. ${ }^{13}$

\section{Precedent}

The OSH Act's purpose and policy section sets out the goal of assuring "safe and healthful working conditions."14 Arguing that the "statement of purpose and policy must be considered in construing other sections of the Act," tion of the term "working conditions" to determine the scope of the hazards amenable to OSHA jurisdiction under the general duty clause. ${ }^{16}$

The Supreme Court formulated a definition of "working conditions" when construing the Equal Pay Act of $1963^{17}$ in Corning Glass Works v. Brennan:18 "[T]he element of working conditions encom-

(discussing feasibility of reducing ambient air lead levels).

${ }^{13}$ OCAW, 741 F.2d at 450 .

14 Occupational Health and Safety Act of 1970, §2(b), 29 U.S.C. $\S 651(b)$ (1982).

16 OCAW, 741 F.2d at 447.

16 See id. at 448.

1729 U.S.C. \& 206(d)(1) (1982).

18417 U.S. 188 (1974). 
passes two subfactors: 'surroundings' and 'hazards.' 'Surroundings' measures the elements, such as toxic chemicals or fumes, regularly encountered by a worker . . . 'Hazards' takes into account the physical hazards regularly encountered ....."19

Judge Bork transferred this definition of working conditions to the OSH Act, reasoning that "[ $t$ ] he language of industrial relations, [used to define working conditions in Corning Glass] . . . is as relevant to the OSH Act as to the Equal Pay Act."20 This is, in effect, an in pari materia $a^{21}$ argument. If two statutes are in pari materia, "impressions derived from one statute should be allowed to influence judgment about how another statute should be interpreted." 22 However, even statutes concerning the same subject matter are not necessarily considered in pari materia, if the objects or purposes of the two statutes are different: ${ }^{23}$ "[A] determination under one statute [should not] be mechanically carried over in the interpretation of another statute involving significantly different considerations and legislative purposes."24

As evidenced by the Supreme Court's construction of the two statutes, the purposes of the OSH Act and the Equal Pay Act were fundamentally different: "Congress' purpose in enacting the Equal Pay Act was to remedy what was perceived to be a serious and endemic problem of employment [sex] discrimination in private industry . . ."2s The purpose of the OSH Act, on the other hand, was "to prevent occupational deaths and serious injuries." ${ }^{26}$ When two statutes have fundamentally different purposes, as do the Equal Pay Act and the OSH Act, it is an abuse of in pari materia construction to use one to define

10 Id. at 202 (footnote omitted).

20 OCAW, 741 F.2d at 448. 1979).

21 "Upon the same matter or subject." BLack's LAW DictionaRy 711 (5th ed.

22 2A C. Sands, Sutherland Statutory Construction $\S 51.03$, at 298 (4th ed. 1973).

23 Id. at $298-99$.

24 Local 1976, United Bhd. of Carpenters v. NLRB, 357 U.S. 93, 110 (1958); $c f$. American Textile Mfrs. Inst. v. Donovan, 452 U.S. 490, 511 n.30 (1981) ("The error of several cases finding a cost-benefit analysis mandate in the [OSH] Act is their reliance on the different language and clear legislative history of the Consumer Product Safety Act to reach their conclusions.") (emphasis added).

The OCAW court focused on the fact that the same term-"working conditions"-is used in both the Equal Pay Act and the OSH Act. In the Equal Pay Act, however, that term derives its meaning from a clear legislative history, see Corning Glass Works v. Brennan, 417 U.S. 188, 202 \& n.20 (1974), that has no relevance to the construction of the OSH Act. The OSH Act's legislative history is silent on the meaning of the term "working conditions."

2s Corning Glass Works v. Brennan, 417 U.S. 188, 195 (1974).

28 Whirlpool Corp. v. Marshall, 445 U.S. 1, 11 (1980). 
the scope of the other. ${ }^{27}$

The second and final case relied on by the OCAW court to define the terms "working conditions" and "hazards" was Southern Railway v. Occupational Safety $\mathcal{O}^{2}$ Health Review Commission. ${ }^{28}$ Southern Railway concerned section (4)(b)(1) of the OSH Act, which is designed to prevent duplicative regulation of the same safety hazard by two different federal agencies. ${ }^{29}$ The Southern Railway court found that "the term 'working conditions' as used in Section 4(b)(1) means the environmental area in which an employee customarily goes about his daily tasks." Jo Judge Bork adopted this definition in OCAW, arguing that "[a]lthough a different section of the Act was involved in Southern Ry., we can think of no reason why the definition given of 'working conditions' should not apply to Section 2(b) [the purpose section] and hence influence the concept of hazards in the general duty clause."31

Again, however, Judge Bork's statutory construction rested on an inadequate foundation. Just as relying on one statute to interpret another may be inconsistent with the rule of in pari materia, so may relying on one section of a statute to interpret another section. ${ }^{32}$ As the Supreme Court has noted, the presumption that identical words used in different parts of the same statute are intended to have the same meaning is not so rigid that it cannot yield to a different interpretation that better effectuates the purpose of the statute: ${ }^{33}$

Most words have different shades of meaning and consequently may be variously construed, not only when they occur in different statutes, but when used more than once in the same statute or even in the same section. . . . Where the scope of the legislative power exercised in one case is broader than that exercised in another, the meaning well may vary to meet the purposes of the law, to be arrived at by a considera-

${ }^{27}$ Cf. Northern Pac. Ry. v. United States, 156 F.2d 346 (1946), aff'd, 330 U.S. 248 (1947) (rejecting use of in pari materia construction where "[i]t is obvious that the Transportation Act of $1940 \ldots$. . is not concerned with the same subject matter . . . so as to call for the application of the rule").

28539 F.2d 335 (4th Cir.), cert. denied, 429 U.S. 999 (1976).

29 Section (4)(b)(1), 29 U.S.C. $\$ 653$ (b)(1) (1982), provides, "Nothing in this chapter shall apply to working conditions of employees with respect to which other Federal agencies, and State agencies acting under section 2021 of Title 42, exercise statutory authority to prescribe or enforce standards or regulations affecting occupational safety or health."

so Southern Railway, 539 F.2d at 339.

s1 OCAW, 741 F.2d at 448.

32 See 2A C. SANDS, supra note 22, at 299.

ss See Atlantic Cleaners \& Dryers, Inc. v. United States, 286 U.S. 427, 433 (1932); Public Utils. Comm'n v. Attleboro Steam \& Elec. Co., 273 U.S. 83 (1927); Lamar v. United States, 240 U.S. 60, 65 (1916). 
tion of the language in which those purposes are expressed, and of the circumstances under which the language was employed. ${ }^{34}$

In its description of the purpose of the OSH Act, the Southern Railway court itself provided a compelling reason why its definition of "working conditions" under section (4)(b)(1) should not be applied to other sections of the statute. Section $4(b)(1)$ is the only section of the Act that exempts hazards from coverage; the remainder of the Act grants authority to the Secretary to regulate hazards. The Southern Railway court explicitly stated that it was defining "working conditions' as used in Section 4(b)(1)."3s This qualification was necessary because section $4(b)(1)$ employs words of limitation in the larger context of a remedial safety statute. The Southern Railway court recognized that section $4(b)(1)$ must be construed narrowly in contrast to the remainder of the Act:

[T] he scope of the Congressional objective requires that this "[r]emedial social legislation [the OSH Act] . . . be construed liberally in favor of the workers whom it was designed to protect, and any exemption from its terms must be narrowly construed." Accordingly, the exemptive statute should appropriately be construed to achieve the maximum protection for the industrial workers of the Nation. ${ }^{36}$

The Southern Railway definition of "working conditions" was developed in the unique context of construing an exemption. Judge Bork's application of this narrow definition to the purpose section both violated a basic tenet of statutory construction and distorted the remedial purpose of the $\mathrm{OSH}$ Act.

\section{Congressional Intent}

Judge Bork adopted the Occupational Health and Safety Review Commission's reading of OSH Act legislative history to infer a congressional intent to exclude employer policies from OSH Act jurisdiction:

The Commission pointed out that the Act does not define the

34 Atlantic Cleaners \& Dryers, Inc. v. United States, 286 U.S. 427, 433 (1932).

ss 539 F.2d at 339 (emphasis added).

se 539 F.2d at 338 (footnote omitted) (quoting Wirtz v. Ti Ti Peat Humus Co., 373 F.2d 209, 212 (4th Cir. 1967)); accord Whirlpool Corp. v. Marshall, 445 U.S. 1, 13 (1980) ("S]afety legislation is to be liberally construed to effectuate the congressional purpose."); $i d$. at 12 ("To accomplish [the OSH Act's] basic purpose, the legislation's remedial orientation is prophylactic in nature."). 
word "hazard" and turned to the legislative history for guidance. "Congressional floor debates [and] committee reports . . . are replete with discussions of air pollutants, industrial poisons, combustibles and explosives, unsafe work practices and inadequate training ....." From this, and other evidence ...., the commission concluded that "Congress conceived of occupational hazards in terms of processes and materials [that operate] directly upon employees as they engage in work related activities."

Congressional concern with tangible hazards should not, however, be read as congressional intent to exclude other types of hazards from the reach of the Act, particularly those unknown at the time of enactment. "The rule that a statute will operate prospectively so as to include circumstances unknown at the time of enactment has been employed in the construction of ... remedial statutes."38 The Supreme Court "frequently has observed that a statute is not to be confined to the 'particular application[s] . . . contemplated by the legislators.' "'s9

Supreme Court cases dealing with the application of a statute to an issue not mentioned in the legislative history support the idea that illustrative applications of the act noted in the legislative history need not necessarily determine the scope of the statute. ${ }^{10}$ Where the legislative history is silent, the Court reads the language of the relevant clause in light of the historical backround of the statute to determine if Congress" "choice of language . . . fairly brings a given situation within a statute."11 Thus, legislative silence alone does not indicate a congressional intent to exclude. A deeper inquiry into the language of the statute is required to determine if a situation, unknown at the time of en-

s7 OCAW, 741 F.2d at 449 (quoting American Cyanimid [sic] Co., 1981 O.S.H. Dec. (CCH) II 25,338, at 31,430, 31,431).

ss 2A C. SANDS, supra note $22, \S 49.02$, at 230 (4th ed. 1973) (footnote omitted).

39 Diamond v. Chakrabarty, 447 U.S. 303, 315 (1980) (quoting Barr v. United States, 324 U.S. 83, 90 (1945)); see also Browder v. United States, 312 U.S. 335, 339 (1941); Puerto Rico v. Shell Co., 302 U.S. 253, 257 (1937).

${ }^{60}$ Puerto Rico v. Shell Co., 302 U.S. 253 (1937), demonstrates the Court's willingness to apply a statute to a situation not specifically contemplated by the legislators:

When the Sherman Act was passed (1890), we had no insular dependencies; and, necessarily, the application of $\S 3$ did not extend beyond our continental domain; and undoubtedly, it was this domain which was in the immediate contemplation of Congress. Certainly, Congress at that time did not have Puerto Rico in mind. But that is not enough. It is necessary to go further and to say that if the acquisition of that insular dependency had been foreseen, Congress would have so varied its comprehensive language as to exclude it from the operation of the act.

Id. at 257.

41 Barr v. United States, 324 U.S. 83, 90 (1945). 
actment, is fairly covered by the act. An analysis of the words of the act and its purpose must demonstrate that, if the situation had been foreseen, Congress would have explicitly excluded it. ${ }^{42}$

Congressional concern with abatement of tangible hazards, as expressed in the legislative history, is not inconsistent with a concern for abatement of other types of hazards to workers. Mere silence in the legislative history on the issue of sterilization requirements provides inadequate support for the finding that Congress intended to exclude such policies from the reach of the Act.

\section{Limiting Liability: The Threat of "Unforeseeable Consequences"}

Defining the limits of employer liability under the OSH Act is a major concern running throughout Judge Bork's OCAW opinion. On no less than four occasions the opinion expresses this concern, referring to the specter of "unforeseen liabilities,"4s "unforeseeable scope," "unforeseeable consequences," 5 and the need to find "some limit to the statute's reach." 18 Judge Bork formulated the case so that the court's only choice was between a legal rule which imposed liability "in all circumstances imaginable"47 and one that immunized hazardous employer policies from the Act.

Given the choice between these two rules, the court's decision to limit liability was reasonably consistent with one of the Act's unstated constraints: "Congress does not appear to have intended to protect employees by putting their employers out of business ..." The The court's interpretation of the Act, however, gave short shrift to the primary purpose of the Act-protection of employee health: "When Congress passed the Occupational Safety and Health Act in 1970, it chose to place pre-eminent value on assuring employees a safe and healthful working environment, limited only by the feasibility of achieving such an environment." 49 Thus, while it would be senseless to suggest that the Act imposes limitless liability on employers, this does not justify the

12 See Puerto Rico v. Shell Co., 302 U.S. 253, 257 (1937).

63 OCAW, 741 F.2d at 449 .

14 Id.

48 Id. at 450.

40 Id. at 449.

47 Id.

48 Industrial Union Dep't v. Hodgson, 499 F.2d 467, 478 (D.C. Cir. 1974). OSH Act requirements may, however, be "financially burdensome," "affect profit margins adversely," and lead to the "economic demise of an employer who has lagged behind the rest of the industry . . . and is consequently unable to comply with new standards." Id.

49 American Textile Mfrs. Inst. v. Donovan, 452 U.S. 490, 540 (1980). The feasibility referred to is both economic and technological. Id. at 513 n.31. 
court's finding that an employer policy requiring women workers to be sterilized or be fired is beyond the scope of the Act.

Judge Bork reasoned that the sterilization policy lay beyond the Act's scope because the harm suffered by sterilized employees resulted not from the policy but rather from the employees' decision to be sterilized as influenced by " 'economic and social factors which operate primarily outside the workplace." "\$80 $\mathrm{He}$ then argued that requiring such a decision could not be an OSH Act "hazard":

Were we to decide otherwise, we would have to adopt a broad principle of unforeseeable scope: any employer policy which, because of employee economic incentives, left open an option exercised outside the workplace [would make] the employer liable under the general duty clause. ${ }^{51}$

Recasting the sterilization policy as an economic and social issue that was external to employment was, however, wrong as a matter of fact and was used to support a conclusion that was wrong as a matter of law.

First, information presented in the union's brief, ${ }^{52}$ and referred to in the OCAW decision itself, ${ }^{\text {,3 }}$ indicates that Judge Bork's characterization of the sterilization requirement was factually inaccurate. American Cyanamid developed the sterilization policy in response to an existent lead hazard. ${ }^{54}$ The policy resulted from company decisions that were within the company's power to modify. American Cyanamid determined that surgical sterilization was the only course for women of childbearing age who wished to retain jobs in the affected areas of the plant. Even a woman whose husband had been surgically sterilized was

so OCAW, 741 F.2d at 449 (quoting American Cyanimid [sic] Co., 1981 O.S.H. Dec. (CCH) II 23,338, at 31,431) ("The decision to be sterilized 'grows out of economic and social factors which operate primarily outside the workplace,' and hence the fetus protection policy is not a hazard within the meaning of the general duty clause." ").

${ }^{\mathrm{si}} I d$.

62 Brief for Petitioners at 2-10, OCAW, 741 F.2d 444.

ss OCAW, 741 F.2d at $445-46$.

st Judge Bork noted prior decisions indicating the economic and technological infeasibility of lowering the ambient air lead level in the inorganic pigments department to 50 micrograms per cubic meter, the level deemed by OHSA to provide minimally acceptable protection for the fetus. See OCAW, 741 F.2d at 446 (citing American Cyanamid Co., 1980 O.S.H. Dec. (CCH) I 24,828 (economically infeasible to reduce ambient air lead levels at Willow Island plant to 200 micrograms per cubic meter)); id. (citing United Steelworkers v. Marshall, 647 F.2d 1189, 1295 (D.C. Cir. 1980), cert. denied, 453 U.S. 913 (1981) (OSHA did not meet burden of showing the technological feasibility of an ambient air lead standard for the pigment industry of 50 micrograms per cubic meter)); see also OSHA Lead Preamble, supra note 3, at 52,966 (stating that compliance with an air standard of 50 micrograms per cubic meter, in addition to other protective measures, "should effectively minimize any risk to the fetus"). 
required to undergo sterilization; the husband's sterility was deemed insufficient to ensure that the woman would avoid pregnancy. ${ }^{55}$

The company's medical and industrial relations personnel conducted educational programs on the nature of the surgery. Women workers were told that sterilization would be required of those women exposed to a number of undisclosed chemicals in use at the Willow Island plant, and that surgical sterilization would become a condition of employment throughout the chemical industry. ${ }^{56}$ The women were also told that their company medical insurance would cover the operation and that sick leave would be provided. ${ }^{.7}$ Finally, and most importantly, the company required women employees to undergo sterilization to keep their jobs. ${ }^{58}$ Given the company's exclusive role in developing and implementing the policy as a response to workplace toxins, it was a factual distortion to describe the decision to be sterilized as resulting from factors external to the workplace. Actually at issue was a mandatory condition of employment imposed on women workers by their employer.

Second, the OCAW court concluded, as a matter of law, that the Secretary did not have the authority under the general duty clause to reach "economic and social factors that operate primarily outside the workplace." where the economic factor in question amounts to forcing women employees to choose between forfeiting their jobs and enduring the certain harm of sterilization.

Before the enactment of the OSH Act, workers could choose to give up their jobs rather than expose themselves to hazards. This was the choice women employees faced at the Willow Island plant. Legislative history and judicial precedent indicate that the OSH Act is intended to prohibit employers from forcing workers to choose between their health and their jobs. In the words of a House report, "Today's law and practices allow workers to receive thousands of cases of occupational disease and illness without any effective protection .... [The worker] should not be economically coerced into a hazardous job." $" 10$

SB See Brief for Petitioners at 4, OCAW.

so See id. at 6.

s7 See OCAW, 741 F.2d at 446.

${ }^{58}$ See id.

so Id. at 449 (quoting American Cyanimid [sic] Co., 1981 O.S.H. Dec. (CCH) I $25,338$, at 31,431$)$.

bo H.R. ReP. No. 1291, 91st Cong., 2d Sess. 29 (1970); see also id. at 30 (The "danger that an employee may be economically coerced into self-exposure in order to earn his livelihood" is unacceptable.). Both of these statements were made during the 
The Supreme Court, in Whirlpool Corp. v. Marshall, ${ }^{\mathbf{6 1}}$ holding that the OSH Act prohibits job discrimination against employees who refuse life-threatening job assignments, ${ }^{62}$ stated, "It would seem anomalous to construe an Act so directed and constructed as prohibiting an employee, with no other reasonable alternative, the freedom to withdraw from a workplace environment that he reasonably believes is highly dangerous." 38 The Whirlpool Court unanimously affirmed the circuit court's holding on the impermissibility of the choice between work and health: "The district courts have sanctioned an employer's right to make workers choose between their jobs and their lives. We cannot agree that the statute was ever intended to require placing an employee in such an untenable position." 64

In Frank Diehl Farms v. Secretary of Labor, ${ }^{\mathrm{B5}}$ a case concerning Occupational Health and Safety Administration (OSHA) regulation of migrant housing, the court, in determining the scope of the Act, considered the extent to which employees were subjected to employer coercion. ${ }^{68}$ The court upheld OSHA's "conditions of employment" test as an appropriate basis to determine jurisdiction. ${ }^{67}$ In this case, the key factor in the test was whether the employer required the workers to reside in the housing or whether an employee elected to do so voluntarily: "Only if company policy or practical necessity force workers to live in employer provided housing is the degree of coercion such that the hazards . . . come under the scope of the Act." ${ }^{\circ 8}$ The court found, as a factual matter, that the employees were not required either by employer policy or geographical necessity to dwell in the apartments ${ }^{6 \theta}$ and

discussion of a proposed version of $\S 19(\mathrm{a})(5)$ of the Act, which would have required OSHA to inform workers of hazards and permitted the worker to "absent himself from such risk of harm for the period necessary to avoid such danger without loss of regular compensation for such period." Id. at 12. This "right to strike" provision was deleted from the final version of the Act. See Whirlpool Corp. v. Marshall, 445 U.S. 1, 14-16 (1980). The report is still relevant because it illustrates congressional concern that employees not be forced to choose between safety and a job, even though a different mechanism for protecting workers from such a choice-the right to request immediate Labor Department inspections-was actually adopted by Congress.

61445 U.S. 1 (1980).

62 The question presented to the Court was whether the OSHA regulation that affords protection from discrimination against employees exercising the right to refuse unsafe work, 29 C.F.R. $\S 1977.12$ (1984), is consistent with the Act.

6845 U.S. at 12.

64 Marshall v. Whirlpool Corp., 593 F.2d 715, 717 (6th Cir. 1979), aff d, 445

U.S. 1 (1980).

65 696 F.2d 1325 (11th Cir. 1983).

Bs See id. at 1333.

67 See id.

-8 Id. (emphasis added).

60 See id. at 1327, 1332-33. 
thus held that OSHA did not have jurisdiction. As a legal matter, however, the decision established a mandatory "condition of employment" test as the criterion for determining OSHA jurisdiction over employerowned migrant housing. ${ }^{70}$ If the workers had been required to live in the employer's housing in order to keep their jobs, such housing would have been subject to OSHA regulation "even though these places would not otherwise be 'workplaces' and even though the hazards ... . are different in kind and quality from most occupational hazards."71

The language of the OCAW decision itself suggests that the American Cyanamid workers' decisions to be sterilized should not be characterized as resulting exclusively from "economic and social factors." Immediately following the "economic and social factors" discussion, the court states that "the Act should not be read to make an employer liable for every employee reaction to the employer's policies."72 Thus, within the same paragraph, the court suggests that a worker's decision to be sterilized results both from "economic and social factors operating primarily outside the workplace," and from employer policies. While it is true that the choices employees make in response to some employer policies necessarily are affected by external "economic and social factors," it is nonsense to characterize a policy designed, implemented, and enforced by the employer as external to the workplace.

\section{B. Potential Impact of OCAW}

The OCAW decision has two notably pernicious consequences. First, lead, the toxin responsible for American Cyanamid's sterilization policy, is just one of many chemicals and physical agents shown to have adverse effects on the offspring of exposed workers. Other recognized hazards include pesticides, ionizing radiation, solvents used in manufacturing rubber, anesthetic gases used in operating rooms, and metals used in the smelting industry. ${ }^{73}$ It is likely that as laboratory and epide-

70 See id. at 1332, 1333.

71 Id. at 1333.

72 OCAW, 741 F.2d at 449.

7s Dibromochloropropane, a pesticide, and lead, associated mainly with the battery industry, have been identified as reproductive hazards acting on sperm. See Klingberg, Papier \& Hart, Birth Defects Monitoring, 117 Progress IN ClinICAL AND Biological Research 309, 314 (1983); see also Meyer, Critical Review of Studies Relating Occupational Exposure of Males and Reproductive Capacity, 160 PROGREss in Clinical and Biological Research 375, 376 (1984); Rom, Effects of Lead on Reproduction, in NATIONAL INSTITUTE For OCCUPATIONAL SAFETY AND HeALTH, U.S. Dep't of Health and Human Servs., Pub. No. 81-100, Proceedings of a

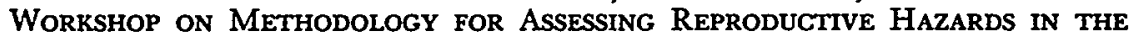
WORKPLACE 33-34 (1980) [hereinafter cited as ProceEdings]. Other chemical or physical agents associated with effects on semen quality include kepone (chlorodecone) 
miological techniques improve more workplace reproductive hazards will be identified. ${ }^{74}$

With the exceptions of the OSHA lead ${ }^{75}$ and ethylene oxide ${ }^{76}$ standards, OSHA has not promulgated regulations regarding reproductive hazards. There is a pressing need for the control of reproductive hazards in a number of industries. ${ }^{77}$ Under the $O C A W$ decision, employers in all industries exposing workers to reproductive hazards could "control" such hazards by requiring that workers of either $\operatorname{sex}^{78}$ be sterilized in order to keep jobs or to be hired.

Second, although the citation contested in OCAW was issued under section 5 of the $\mathrm{OSH}$ Act-the general duty clause-the language of the $O C A W$ decision is not confined to section 5. Judge Bork found that the term "hazard" in the general duty clause applied not to employer policies but only to "physical condition[s] of the workplace,"79 that is,

and ionizing radiation.

A series of studies in Sweden of female copper smelter workers who had been exposed to copper, lead, arsenic, cadmium, and sulfur dioxide showed an increased frequency of spontaneous abortions and malformations in offspring. See Hemminki, Axelson, Niemi \& Ahlborg, Assessment of Methods and Results of Reproductive Occupational Epidemiology: Spontaneous Abortions and Malformations in the Offspring of Working Women, 117 Progress in Clinical and BIological Research 293, 300 01 (1983), reprinted in 4 AM. J. InDUS. MED. 293, 300-01 (1983) [hereinafter cited as Hemminki \& Axelson]. Scandinavian studies have indicated that female chemical and rubber workers exposed to various solvents have experienced higher rates of adverse reproductive effects than unexposed control groups. See id. at 301-02. Exposure of operating room personnel to anesthetic gases has been associated with an increased risk of spontaneous abortions. See id. at 302; Cohen, Waste, Anesthetic Gas and Reproductive Health in Operating Room Personnel, in ProceEdings, supra, at 73. Maternal exposure to pesticides has also been associated with defects in offspring. See Hemminki \& Axelson, supra, at 304-05. For a discussion of several early studies on the effects of lead on reproduction, see Procendings, supra, at 33-34.

74 See Meyer, supra note 73, at 381 ("With the discovery of new sensitive laboratory analytical techniques and the use of sophisticated epidemiological methods, new studies will help define the impact of occupational exposures to chemical and physical agents on the reproductive potential of man.").

${ }^{76}$ See OSHA Occupational Safety and Health Standards, Toxic and Hazardous Substances: Lead, 29 C.F.R. § 1910.1025 (1984).

${ }^{78}$ See OSHA Occupational Safety and Health Standards, Toxic and Hazardous Substances: Ethylene Oxide, 29 C.F.R. $§ 1910.1047$ (1984).

${ }_{77}$ Cf. Ashford \& Caldart, The Control of Reproductive Hazards in the Workplace: A Prescription for Prevention, 5 INDUS. REL. L.J. 523, 529 (1983) ("The human risks posed by reproductive hazards in the workplace are both serious and farreaching.").

${ }^{78}$ Judge Bork's analysis in no way depended on the sex of the workers affected by American Cyanamid's policy; the result would have been the same if men had been singled out for sterilization. The company was cited by OSHA for creating a hazard to workers, not for sex discrimination. The fact that the policy applied only to women would have been relevant if the court reached the abatement inquiry described supra note 12.

79 $O C A W, 741$ F.2d at 444. 
to tangible hazards such as chemical fumes or unsafe machines. The $O C A W$ court's definition of "hazard" followed from the prior definition it gave to "working conditions." "Working conditions" is a key term in section 2 of the Act, the statement and purpose section: "The Congress declares it to be its purpose and policy . . . to assure so far as possible every working man and woman in the Nation safe and healthful working conditions and to preserve our human resources . . . ."80

Reasoning that the purpose section bears on other sections of the Act, ${ }^{81}$ the court found that the definition of "working conditions" "influence[s] the concept of 'hazards' in the general duty clause."8? Neither the term "working conditions" nor "hazards" is defined by the statute. In defining these two key statutory terms, the $O C A W$ court has limited the Secretary's authority under both section 5, the "general duty" section and section $6,^{83}$ the standard-setting section. Both sections use the term "hazard" and both sections would be influenced by the purpose section's definition of "working conditions." Consequently, the impact of OCAW goes beyond the "general duty clause" and reaches the Secretary's general regulatory authority. The $O C A W$ decision suggests that OSHA lacks the authority not only to cite employers for hazardous policies under the general duty clause, but also to prohibit such policies under section 6 standards. Under the OCAW court's construction of the Act, company policies not concerning physical conditions of the workplace, yet having an impact on employee health, would fall beyond the scope of the Act.

One example of an employer policy that is harmful to worker health is a requirement that employees undergo prophylactic chelation therapy. Prophylactic chelation is the routine administration of chelating agents to reduce the level of lead in the blood. Because chelating agents have dangerous side effects, including liver and kidney damage, nausea, nervousness, and transient high blood pressure, the medical consensus is that chelation should be used only as an emergency measure to treat manifest symptoms of lead poisoning, not as routine prophylaxis. $^{84}$ In a provision of the OSHA lead standard, promulgated pursuant to the Secretary's section 6 regulatory authority, OSHA prohibited employers from implementing policies calling for prophylactic (1982).

Bo Occupational Safety and Health Act of $1970, \S 2$ (b), 29 U.S.C. $\S$ 651(b)

81 See OCAW, 741 F.2d at 447 ("This statement of purpose and policy must be considered in construing all other provisions of the Act.").

82 Id. at 448.

8s Occupational Health and Safety Act of 1970, § 6, 29 U.S.C. $\S 655$ (1982).

84 See OSHA Lead Preamble, supra note 3, at 53,001-02. 
chelation..$^{85}$ In short, OSHA concluded that prophylactic chelation is "unacceptable whatever the setting," whether in the workplace or in the doctor's office. ${ }^{88}$ The $O C A W$ decision, in that it defines hazards to exclude employer policies, undermines the Secretary's authority as exercised in promulgating and enforcing the regulation banning prophylactic chelation.

Policies requiring sterilization and prophylactic chelation are similar: both cause harm to the employee outside the workplace, and both are imposed as a condition of employment. The OSHA ban on prophylactic chelation focuses on the employer's role in requiring workers to undergo harm. Similarly, it was the employer's role in requiring workers to undergo the harm of sterilization that the Secretary tried to regulate by requiring abatement of the American Cyanamid sterilization policy. Effectively, employees are economically coerced to conform with both policies. ${ }^{87}$ The ban on prophylactic chelation demonstrates that worker health will receive inadequate protection unless OSHA authority extends beyond tangible workplace hazards. If courts adopt the $O C A W$ rationale in other contexts, industries will be free to adopt dangerous policies-similar to a prophylactic chelation requirement-unhampered by OSHA regulation.

\section{Finding the Limit of the Act: An Alternative APPROACH TO OSHA JURISDICTION}

The $O C A W$ decision rested on two problematic assumptions. First, the court assumed that all worker health hazards result exclusively either from "tangible hazards such as chemicals"8s or from "economic and social conditions acting primarily outside the workplace."s9 Second, having established this rigid characterization scheme, the court assumed that the Act could reach only the tangible threats to worker health and safety. In the real world of worker health, however, many hazards will not be understood, identified, or remedied under this rigid scheme.

Having decided that employers would be faced with limitless lia-

ss See 29 C.F.R. § 1910.1025(j)(4) (1984) (prohibiting prophylactic chelation but allowing therapeutic or diagnostic chelation under medical supervision).

${ }_{86}$ OSHA Lead Preamble, supra note 3, at 53,002.

87 In United Steelworkers v. Marshall, 647 F.2d 1189 (D.C. Cir. 1980), cert. denied, 453 U.S. 913 (1981), the Court noted that "workers often consumed self-prescribed chelating agents, and lied to physicians about their subjective symptoms, all because they held job security more dear than their health." Id. at 1237 (footnote omitted).

${ }^{88}$ OCAW, 741 F.2d at 449. at 31,431 .

${ }^{89}$ Id. (quoting American Cyanimid [sic] Co., 1981 O.S.H. Dec. (CCH) If 25,338, 
bility if hazards related to economic and social factors gave rise to OSHA jurisdiction, Judge Bork, in effect, created a choice between two draconian $^{80}$ alternatives: limitless liability or no liability at all. Opting for the latter alternative forced an inappropriately narrow interpretation of the statute that nullified the effect of language in fundamental sections of the Act. ${ }^{91}$ A more realistic and flexible view of the multiplicity of factors that create worker health hazards would have allowed the court to give effect to the dual concerns of protecting employee health and limiting employer liability.

The following examination of the language and history of the $\mathrm{OSH}$ Act and of cases interpreting the Act suggests a more balanced approach: courts should focus on the employer's role in creating hazards. Under this approach, liability follows responsibility; the Act protects workers from the hazards of their employment without regard to artificial and unrealistic categories, and employers are liable only for those hazards that their actions create.

\section{A. Statutory Language and Legislative History}

The two central sections of the Act discussed by the OCAW court-the purpose section and the general duty clause-contain language that suggests a substantially broader construction of the Act than the one formulated by Judge Bork. First, in the Act's purpose section, Congress established the goal not only of achieving "safe and healthful working conditions," but also of "preserving . . . human resources."92 The hazard alleged by the Secretary in OCAW destroyed human resources in that it led to the loss of workers' reproductive capacities. A long-recognized rule of statutory construction holds that "effect must be given, if possible, to every word, clause, and sentence of a statute;"'ss yet the OCAW court, in construing the purpose section of the statute, omitted the "preservation of human resources" language. If, as Judge Bork asserted, the Act's provisions must be defined in light of the purpose

90 Ironically, the term "draconian" has been used in criticizing policies designed to protect the environment. See Bethlehem Steel Corp. v. Train, 544 F.2d 657, 661 (3d Cir. 1976) ("The draconian consequences of EPA's strict insistence on the July 1, 1977 deadline, Bethlehem contends, is inconsistent with Congressional awareness of the unwelcome economic impact of the overly zealous pursuit of environmental goals."); see also California v. Bergland, 483 F. Supp. 465,489 (E.D. Cal. 1980) ("a draconian choice between the extreme of all wilderness, and ten other alternatives").

91 See infra notes 92-98 and accompanying text. (1982).

${ }^{22}$ Occupational Safety and Health Act of 1970, § 2(b), 29 U.S.C. $\S$ 651(b)

93 2 A C. SANDS, supra note $22, \S 46.06$, at 63. 
clause, "hazards" as used in the general duty clause should be read to include both unsafe or unhealthful working conditions and the destruction of human resources. So construed, American Cyanamid's sterilization policy belongs within the scope of the Act.

Second, the general duty clause indicates a concern for worker health that extends beyond physical conditions of the workplace. The clause requires the employer to furnish both "employment and a place of employment which are free from recognized hazards." 950 The legislative history describes the duty imposed on employers as prohibiting those actions that bring harm to workers, ${ }^{96}$ and nowhere is this prohibition limited to physical conditions of the workplace or tangible hazards. If it were so limited, the inclusion of both "employment" and "place of employment" in the general duty clause would be redundant. If Congress intended to limit an employer's duty to the provision of a workplace free of physical hazards, only "place of employment" need have been mentioned. The Senate report's ${ }^{97}$ explanation of the general duty clause indicates that it was meant to cover broadly employer actions that result in harm to employees: "The committee believes that employers are equally bound by this general and common duty to bring no adverse effects to the life and health of their employees throughout the course of their employment."98

Throughout the OSH Act there are provisions that reach beyond the physical conditions of the workplace. The Act creates legal rights under which the employee can protect her health and job. ${ }^{99}$ The Senate report's discussion of the Act and its purpose ${ }^{\mathbf{1 0 0}}$ shows that Congress

24 See OCAW, 741 F.2d at 447.

95 Occupational Safety and Health Act of $1970, \S 5(a)(1), 29$ U.S.C. $\S 654(a)(1)$

(1982) (emphasis added).

${ }^{98}$ See infra note 98 and accompanying text.

97 Senate Subcomm. on Labor of the Comm. on Labor and Public WelFare, 92D Cong., 1st Sess., Legislative History of the OCcupational Safety and Health ACt 905 (Comm. Print 1971) [hereinafter cited as Legislative HISTORY].

${ }^{98} I d$. at 149.

99 To ensure that this process functions effectively, the Act expressly accords to every employee several rights, the exercise of which may not subject him to discharge or discrimination. An employee is given the right to inform OSHA of an imminently dangerous workplace condition or practice and request that OSHA inspect that condition or practice. 29 U.S.C. $\S 657(\mathrm{f})(1)$. He is given a limited right to assist the OSHA inspector in inspecting the workplace, $\S \S 657(\mathrm{a})(2)$, (e), and $(\mathrm{f})(2)$, and the right to aid a court in determining whether or not a risk of imminent danger in fact exists. See $\S 660$ (c)(1). Finally, an affected employee is given the right to bring an action to compel the Secretary to seek injunctive relief if he believes the Secretary has wrongfully declined to do so. $\S 662(\mathrm{~d})$.

Whirlpool Gorp. v. Marshall, 445 U.S. 1, 9-10 (1980).

${ }^{100}$ Legislative History, supra note 97, at 142. 
intended to attack the problem of risks to employee health in its scientific, ${ }^{101}$ ethical, ${ }^{102}$ medical, ${ }^{103}$ and social ${ }^{104}$ dimensions. In upholding the lead standard, the Court of Appeals for the D.C. Circuit echoed this concern for providing the Secretary of Labor with broad authority:

The face of the statute and the legislative history both demonstrate unmistakably that OSHA's statutory mandate is, as a general matter, broad enough to include such a regulation as MRP [medical removal protection]. A number of terms of the statute give OSHA almost unlimited discretion to devise means to achieve the congressionally mandated goal. Thus OSHA is to ensure worker safety and health "by developing innovative methods, techniques, and approaches for dealing with occupational safety and health problems[.]"

... In the OSH Act Congress invested a new agency with extremely broad jurisdiction to prevent all types of safety and health hazards throughout American industry. ${ }^{105}$

\section{B. Case Law}

The statutory provisions and legislative history discussed above

$101 C f$. Occupational Safety and Health Act of 1970, $\S 2(\mathrm{~b})(5)-(6), 29$ U.S.C. $\S 651(b)(5)-(6)(1982)$ :

The Congress declares it to be its purpose and policy . . . to assure so far as possible every working man and woman in the nation safe and healthful working conditions and to preserve our human resources-

(5) by providing for research in the field of occupational safety and health, including the psychological factors involved, and by developing innovative methods, techniques, and approaches for dealing with occupational safety and health problems;

(6) by exploring ways to discover latent diseases, establishing causal connections between diseases and work in environmental conditions, and conducting other research relating to health problems, in recognition of the fact that occupational health standards present problems often different from those involved in occupational safety ....

102 See Legislative History, supra note 97, at 143.

${ }^{103}$ See id. at 142; cf. Occupational Safety and Health Act of 1970, § 2(b)(7), 29 U.S.G. § 651(b)(7) (1982): ("providing medical criteria which will assure insofar as practicable that no employee will suffer diminished health, functional capacity, or life expectancy as a result of his work experience").

104 See Legislative HistoRx, supra note 97, at 145.

108 United Steelworkers v. Marshall, 647 F.2d 1189, 1230, 1232 (D.C. Gir. 1980), cert. denied, 453 U.S. 913 (1981) (quoting Occupational Safety and Health Act of $1970, \S 2(b)(5), 29$ U.S.C. $\S 651(b)(5)$ (1982) (citations and footnotes omitted). 
demonstrate a congressional concern not only with the tangibility and location of occupational hazards, but also with the employer's role in creating them. In determining the scope of OSHA jurisdiction, courts have considered various factors, including conditions of employment, ${ }^{108}$ economic coercion of employees, ${ }^{107}$ and work-relatedness of hazards. ${ }^{108}$ What unifies these considerations is a concern with the employer's role in the creation of hazards. While this Comment argues that OSHA should have jurisdiction where the employer contributes to the creation of the hazard, the $O C A W$ court has precluded substantial inquiry into employer policies that are hazardous to employees by its categorical differentiation between "tangible" and "economic and social" factors. Other courts, however, have considered factors from both of these categories, in addition to factors more appropriately characterized as somewhere in between, to determine if the employer's role in creating the hazard was sufficient to support a finding of OSHA jurisdiction.

In Frank Diehl Farms v. Secretary of Labor, ${ }^{109}$ the court used a "condition of employment" test to determine whether the "degree of coercion [brought] the hazards of apartment living"110 within the scope of OSHA jurisdiction. The court conceived of the hazard as resulting both from the tangible conditions of the housing and the "practical, economical, ... or physical" necessities of migrant employment, ${ }^{111}$ and established that an employer requirement or geographic necessity to dwell in the housing would serve as a basis for OSHA jurisdiction. ${ }^{112}$ 1983).

${ }^{108}$ See Frank Diehl Farms v. Secretary of Labor, 696 F.2d 1325, 1333 (11th Cir.

${ }_{107}$ See Marshall v. Whirlpool Corp., 593 F.2d 715, 717 (6th Cir. 1979), affd, 445 U.S. 1 (1980); see also supra text accompanying notes 65-68.

${ }_{108}$ See Forging Indus. Ass'n v. Secretary of Labor, 748 F.2d 210, 214 (4th Cir. 1984); see also infra text accompanying notes 119-21.

The legal rule proposed in this Comment, which employs a concept of "work relatedness," must be distinguished from the Commission discussion of "work relatedness," cited with approval by Judge Bork: "Congress conceived of occupational hazards in terms of processes and materials which cause injury or disease by operating directly upon employees as they engage in work or work-related activities." "OCAW, 741 F.2d at 449. The Commission and Judge Bork did not seem to view the act of registering in a hospital and undergoing surgical sterilization as a "work-related activity," even when such an act was a condition of employment. This reasoning, however, would probably remove from the category of "work-related activity" the act of undergoing employer-required prophylactic lead chelation therapy in a doctor's office. This Comment's approach requires that any activity carried out as a condition of employment must be viewed as "work-related."

109696 F.2d 1325 (11th Cir. 1983).

110 Id. at 1333.

111 Id.

112 Id. 
In United Steelworkers $v$. Marshall, ${ }^{113}$ the D.G. Gircuit Court of Appeals considered economic factors, namely employee wage and seniority rights, in evaluating employer responsibility for the treatment of lead-exposed workers. The case concerned an industry challenge to several provisions of the OSHA-promulgated lead standard, including the medical removal protection (MRP) provisions. ${ }^{114}$ The Steelworkers court considered both the tangible hazards of lead poisoning and the impact of the employers' job security policy on workers suffering from lead exposure:

Here, we have no trouble upholding the agency's decision as reasonable and well grounded in the evidence. . . .

OSHA found .... that unless workers were guaranteed all their wage and seniority rights upon removal, they would resist cooperating with the medical surveillance program that determined the need for removal, since they reasonably might fear being fired or sent to lower-paying jobs if they revealed dangerously high blood-lead levels. The record showed that workers often consumed self-prescribed chelating agents, and lied to physicians about their subjective symptoms, all because they held job security more dear"than their health. ${ }^{115}$

In a post-OCAW case from the Fourth Circuit, Forging Industry

113647 F.2d 1189 (D.C. Cir. 1980), cert. denied, 453 U.S. 913 (1981).

114 See id. at 1229-30 (MRP requires that the employer "must maintain the worker's earnings and seniority rights ... for a period of 18 months" when the lead standard mandates worker removal from the job due to high lead content in the blood.); see also OSHA Occupational Safety and Health Standards, Toxic and Hazardous Substances: Lead, 29 C.F.R. § 1910.1025(k) (1984).

115647 F.2d at 1237. The court also considered social factors in upholding the Multiple Physician Review Mechanism of the lead standard:

Lacking total trust in both the honesty and the competence of company doctors, OSHA included in its detailed rules on medical surveillance a scheme called the Multiple Physician Review Mechanism.

.. [A]ny device designed primarily to enhance workers' confidence in the physicians who examine them for lead disease will in turn enhance their health, since an employee who trusts the integrity and skill of the examining physician will more likely cooperate in, and thereby improve the accuracy of, the examination.

Id. at 1238-39 (footnote omitted). But see American Textile Mfrs. Inst. v. Donovan, 452 U.S. 490 (1980), in which the Supreme Court did not decide the question of OSHA authority to require wage protection of employees transferred from high cotton dust areas because they were unable to wear a respirator. The Court held that OSHA had "failed to make the necessary determination or statement of reasons that its wage guarantee requirement is related to the achievement of a safe and healthful work environment." Id. at 537-38. 
Association $v$. Secretary of Labor, ${ }^{116}$ the court adopted a work-relatedness test for determining OSHA jurisdiction over employer actions that may create a hazard of hearing loss from noise exposure. ${ }^{117}$ The core of the work-relatedness test is a determination of employer responsibility for creating the hazard. The case concerned a challenge to a hearing conservation amendment of the OSHA occupational noise exposure standard. The amendment compelled employers to institute remedial measures-including medical tests, industrial hygiene controls, educational training, and records retention-for the protection of employees who had suffered a hearing loss known as a standard threshold shift (STS). ${ }^{118}$

In Forging Industry, the majority and the dissent agreed that a work-relatedness test was appropriate; they disagreed, however, on the factual characterization of the hazard. The majority found that the amendment compelled the employer to institute remedial measures even if the STS resulted from hazards existing outside the workplace (nonoccupational noise exposure) such as "hunting rifles [or] . . . loud music."119 The majority vacated the amendment because it found that the amendment made "no distinction between hearing loss caused by workplace sources and loss caused by non-workplace sources."120 The majority found that the work-relatedness of the noise hazard targeted by the amendment could not be clearly established.

The dissent, also applying a work-relatedness test, ${ }^{121}$ criticized the majority decision on two grounds: first, the majority did not sufficiently defer to the Secretary's conclusion that the hearing loss covered by the amendment was employment-related; and second, the majority mischaracterized the factual nature of the hazard. On its second point of disagreement, the dissent offered this analogy:

Breathing automobile exhaust and general air pollution, for example, is not healing to a wounded lung. That hardly justifies failure to regulate noxious workplace fumes that inflicted the primary wound. Nor would there be logic to characterizing regulation of the fumes as non-occupational because the condition inflicted is aggravated by outside irritants. ${ }^{122}$

118748 F.2d 210 (4th Gir. 1984).

117 See id. at 214.

118 See OSHA Occupational Health and Environmental Control: Occupational Noise Exposure, 29 C.F.R. $\S 1910.95$ (1984).

110748 F.2d at 214.

120 Id.

121 See id. at 215 (Sprouse, C.J., dissenting).

122 Id. at 216. 
According to the dissent, the occupational noise exposure could be characterized as the "primary risk factor" involved in hearing loss. ${ }^{123}$

Although Forging Industry, Steelworkers, and Frank Diehl Farms concern standards developed under section 6 of the OSH Act, and $O C A W$ concerns a citation under the Section 5 general duty clause, each of these cases addresses the scope of the Act. In the three section 6 cases discussed, the employer's role in creating the hazard was determinative on the question of OSHA authority or jurisdiction. In Frank Diehl Farms, because the employer allowed workers the choice of living either in migrant housing or in other housing, ${ }^{124}$ the court held that the employer's role in creating the hazard was insufficient to support OSHA jurisdiction. In Steelworkers, the court identified a significant employer role in creating economic disincentives for workers to participate in a lead disease medical screening program; OSHA therefore had the authority to intervene and eliminate these disincentives. ${ }^{125}$ In Forging Industry, the majority and the dissent disagreed as to the workrelatedness of the hearing loss over which OSHA had assumed jurisdiction. The majority vacated the amendment because it found that employers could not be held liable for noise hazards, such as rock music, that they had no role in creating. ${ }^{128}$

The disagreement between the majority and the dissent in Forging Industry demonstrates that the inquiry into the employer's role in creating a hazard does not provide clear answers in all cases. Using this line of inquiry as a basis of determining OSHA jurisdiction does, however, avoid the unrealistic categorizing of causal factors of worker health hazards as either "tangible" or "economic and social." A focus on the employer's role in creating hazards also forces courts to recognize and consider that often employer policies have characteristics of both categories. Finally, determining OSHA jurisdiction based on the employer's role in creating the hazard establishes an acceptable middle ground between two draconian rules of law: on the one hand, a rule that finds employers liable 'in all circumstances imaginable' and, on the other, a rule that immunizes employer policies from the Act. Where, as with American Cyanamid's sterilization policy, the employee harm results from an employee fulfilling a condition of employment, the employer's role in creating the hazard should support a finding of OSHA jurisdiction.

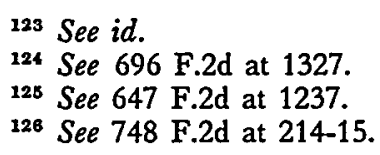




\section{ConCLUSION}

In the fifteen years of the OSH Act's existence, the Secretary has acted to prevent lead disease and other dangerous occupational hazards by exercising broad authority. The Secretary has regulated in such divergent realms as temporary labor camps, ${ }^{127}$ worker access to medical records, ${ }^{128}$ prevention of discrimination against employees exercising statutory rights, ${ }^{129}$ worker education, ${ }^{130}$ worker choice of physicians, ${ }^{131}$ and wage protection of workers suffering from lead exposure. ${ }^{132}$ Prevention of future occupational health problems, particularly in the area of genetic and reproductive hazards, will require creative public health intervention. Such hazards could vary considerably from worker to worker, as a function of either genetic characteristics or family planning attitudes. These variables may be the subject of controversial employer policies, whether implemented merely to avoid liability or to prevent illness and injury in the workplace. In either case, if such a policy is deemed to operate beyond the physical conditions of the workplace, it will be immune from OSHA regulation under Judge Bork's construction of the Act. Ensuring that such policies do not unnecessarily harm workers or coerce them into substituting job security for health requires the delegation of a flexible and broad authority to the Secretary. The legislative history cited by the D.C. Circuit in United Steelworkers v. Marshall ${ }^{133}$ reflects such an awareness: "Neither bill contains . . . a list of specific “do's and don'ts" for keeping workplaces safe and healthful. Industrial safety and health problems are as complex and changing as American industry itself. They cannot be solved by a lengthy list of prohibitions spelled out in a statute." "134

The construction of the $\mathrm{OSH}$ Act formulated in OCAW prohibits the Secretary from reaching hazards resulting from factors deemed to

${ }^{127}$ See OSHA General Environmental Controls: Temporary Labor Camps, 29 C.F.R. § 1910.142 (1984).

${ }_{128}$ See OSHA General Safety and Health Provisions: Access to Employee Exposure and Medical Records, 29 C.F.R. $\S 1910.20$ (1984).

128 See Discrimination Against Employees Under the Williams-Steiger Occupational Safety and Health Act of 1970: Exercise of any Right Afforded by the Act, 29 C.F.R. § 1977.12 (1984).

${ }_{130}$ OSHA has provided grants for worker health and safety education and training programs ("New Directions Training and Education Grants") pursuant to the Secretary's authority under the Occupational Health and Safety Act, 29 U.S.C. $§ 670$ (1982). See 48 Fed. Reg. 46,108 (1983).

${ }_{131}$ See OSHA Occupational Safety and Health Standards, Toxic and Hazardous Substances: Lead, 29 C.F.R. \& 1910.1025(j)(3)(iii) (1984).

${ }^{232}$ See id. § 1910.1025(k)(2)(i)-(iii).

133647 F.2d 1189 (D.C. Cir. 1980), cert. denied, 453 U.S. 913 (1981). 297-98).

134 Id. at 1230 (quoting Senator Saxbe, LegisLATIVE History, supra note 97, at 
be "economic and social." Only tangible hazards such as chemical fumes and unsafe machines seem to be within the Act's scope. If followed, this decision may preclude the Secretary from preventing a whole range of dangerous and harmful industry policies. Thus it is suggested that courts reject Judge Bork's interpretation of the OSH Act and formulate legal standards that allow the Act to function to protect workers as Congress intended it to. The formulation proposed here-liability following from an employer's hazard-creating actions-both protects the American worker and places liability where it is due. 
